\title{
Phytochemical Analysis Reveals an Antioxidant Defense Response in Lonicera Japonica To Cadmium-Induced Oxidative Stress
}

Chengcheng Li

Liaoning University

Yi Tang

Liaoning University

Fengwu Gu

Liaoning University

Xiaoqian Wang

Liaoning University

Wei Yang

Chinese Academy of Sciences

Yang Han

Liaoning University

Yanan Ruan ( $\square$ ruanyanan@Inu.edu.cn )

Liaoning University

\section{Research Article}

Keywords: antioxidant, defense, cadmium-induced, ROS

Posted Date: October 18th, 2021

DOl: https://doi.org/10.21203/rs.3.rs-959884/v1

License: (c) (i) This work is licensed under a Creative Commons Attribution 4.0 International License.

Read Full License 


\section{Abstract}

Cadmium (Cd), though potentially beneficial at lower levels to some plant species, at higher levels is a toxic metal that is detrimental to plant growth and development. Cadmium is also a carcinogen to humans and other contaminated plant consumers, affecting the kidneys and reducing bone strength. In this study we investigated responses of growth, chlorophyll content, reactive oxygen species (ROS) levels, and antioxidant responses to $\mathrm{Cd}^{2+}$ in honeysuckle leaves (Lonicera japonica Thunb.), a potential cadmium hyperaccumulator. Results indicated that plant height, dry weight, leaf area, and chlorophyll content increased when honeysuckle was exposed to 10 or $30 \mathrm{mg} / \mathrm{kg} \mathrm{Cd}^{2+}$ (low concentration). However, in response to 150 or $200 \mathrm{mg} / \mathrm{kg} \mathrm{Cd}^{2+}$ (high concentration) these growth parameters and chlorophyll content significantly decreased relative to untreated control plant groups. Higher levels of superoxide radical $\left(\mathrm{O}_{2}{ }^{-}\right)$and hydrogen peroxide $\left(\mathrm{H}_{2} \mathrm{O}_{2}\right)$ were observed in high concentration $\mathrm{Cd}^{2+}$ groups. The activities of ascorbate peroxidase (APX), monodehydroascorbate reductase (MDAR), dehydroascorbate reductase (DHAR), and glutathione reductase (GR) were enhanced with exposure to increasing levels of $\mathrm{Cd}^{2+}$. Additionally, the AsA-GSH cycle was activated for the removal of $\mathrm{H}_{2} \mathrm{O}_{2}$ in honeysuckle in response to elevated $\mathrm{Cd}^{2+}$. The Pearson correlation analysis, a redundancy analysis (RDA), and a permutation test indicated that proline and APX were dominant antioxidants for removing $\mathrm{O}_{2} \cdot{ }^{-}$and $\mathrm{H}_{2} \mathrm{O}_{2}$. The antioxidants GSH and NPTs also increased as the concentration of $\mathrm{Cd}^{2+}$ increased.

\section{Introduction}

The ecological disruption caused by heavy metal soil contamination has been growing due to urbanization and industrialization as well as the increase in soil cadmium content produced through commonly used phosphate soil fertilization [1]. Cadmium (Cd) is the most common toxic contaminant found in soils [2, 3]. It is readily absorbed by plant roots, transported to above-ground tissues, and absorbed by higher organisms when the contaminated plants are ingested even when the contaminant level is below the phytotoxicity threshold $[4,5]$.

$\mathrm{Cd}$ accumulation reduces growth and negatively affects metabolic factors in plants, thus impacting their basic developmental, physiological, and biochemical processes [6, 7]. Research indicates that $\mathrm{Cd}^{2+}$ alters photosynthesis, damages the internal structure of chloroplasts, inhibits the biosynthesis of chlorophyll, which as a result decreases chlorophyll content and causes leaf chlorosis $[8,9]$. Excessive $\mathrm{Cd}^{2+}$ also has a negative impact on plant water relations which induces a water deficit, alters ion homeostasis, inhibits nutrient uptake of essential minerals such as $\mathrm{Fe}$ and $\mathrm{Ca}$, all of which have a negative effect on plant growth [10-12]. Therefore, high levels of $\mathrm{Cd}^{2+}$ in plants result in wilting and eventually in plant mortality $[13,14]$.

$\mathrm{Cd}$ is not a redox metal. It cannot directly participate in Fenton and Haber-Weiss reactions to produce reactive oxygen species (ROS) $[15,16]$. However, $\mathrm{Cd}^{2+}$ impairs electron transport in mitochondria and chloroplasts, alters enzyme activity, and induces the production of ROS [17]. Excessive production and 
accumulation of ROS, such as superoxide anion $\left(\mathrm{O}_{2} \cdot{ }^{-}\right)$and hydrogen peroxide $\left(\mathrm{H}_{2} \mathrm{O}_{2}\right)$, alter the redox status of cells, resulting in oxidative injury, evidenced as an increase in ion leakage, lipid peroxidation, and DNA-strand cleavage [18]. Some plants have evolved a defense response against $\mathrm{Cd}^{2+}$ and $\mathrm{ROS}$ accumulation, which includes activation of an antioxidant system and the production of osmoprotectants $[12,19]$. Enzymatic antioxidants include superoxide dismutase (SOD), catalase (CAT), ascorbate peroxidase (APX), monodehydroascorbate reductase (MDAR), dehydroascorbate reductase (DHAR), glutathione reductase (GR), and glutathione-S-transferase (GST), while non-enzymatic antioxidants include molecules such as ascorbic acid (AsA) and glutathione (GSH) [20]. Enzymatic and non-enzymatic antioxidants are associated with the ascorbate-glutathione pathway which is one of the effective ways to scavenge $\mathrm{H}_{2} \mathrm{O}_{2}$ in plant cells [21]. AsA acts as an electron donor to process $\mathrm{H}_{2} \mathrm{O}_{2}$ into water and oxygen through APX catalysis reducing oxidative damage. In addition, DHAR and MDAR are responsible for AsA regeneration [22]. GSH and NADPH also act as electron donors and are involved in $\mathrm{H}_{2} \mathrm{O}_{2}$ degradation [22].

Glutathione can indirectly scavenge Cd-induced ROS. The change in the ratio of GSH and its oxidized form (GSSG) acts as a redox pair to modulate the signaling of antioxidant mechanisms in cells [20,23]. When the GSH/GSSG ratio is balanced, plants can reduce or eliminate the oxidative stress caused by cadmium. Once the balance is disturbed as a result of high levels of ROS, plants will experience oxidative damage [24]. Non-protein thiols (NPTs) are low molecular compounds in plant cells such as cysteine, glutathione, phytochelatins, metallothioneins [25]. These small molecules combine with free $\mathrm{Cd}$ to form complexes such as $\mathrm{Cd}-\mathrm{GSH}$ and Cd-PC. The complexes are then compartmentalized in vacuoles, and thus no longer participate in $\mathrm{Cd}^{2+}$ toxic reactions $[26,27]$. Proline, a signaling molecule, is an important osmoprotectant and antioxidant [28] which functions to maintain the redox balance in cells acting as a free radical scavenger, metal chelator, cell membrane stabilizer, and activator of the ROS detoxification pathway [2830]. The accumulation of proline was shown to be related to $\mathrm{Cd}^{2+}$-induced iron deficiency and the inhibition of electron transport activity [31,32].

Honeysuckle (Lonicera japonica Thunb.) is a twining, semi-evergreen vine, distributed widely in temperate and tropical regions [33,34]. It is a popular landscape plant with high environmental adaptability [35]. Honeysuckle has a high $\mathrm{Cd}^{2+}$ tolerance and a strong tendency to accumulate $\mathrm{Cd}^{2+}$. Its shoot $\mathrm{Cd}$ concentration reached $286.12 \mu \mathrm{g} / \mathrm{g}$ DW when exposed to $25 \mathrm{mg} / \mathrm{L} \mathrm{Cd}^{2+}$ for 20 days [36]. Honeysuckle is regarded as a potential cadmium hyperaccumulator [36], however, the biological and chemical mechanisms of cadmium enrichment have not been sufficiently revealed in previous studies. In the present study, the morphological and physiological responses of honeysuckle to elevated levels of $\mathrm{Cd}^{2+}$ were explored. The non-enzymatic antioxidant contents and antioxidant enzyme activities were monitored along with ROS levels in honeysuckle in response to various levels of $\mathrm{Cd}^{2+}$. Redundancy analysis (RDA) and a permutation test were used to identify the crucial components of the antioxidant system.

\section{Results}


Effects of $\mathrm{Cd}^{2+}$ levels on plant growth and chlorophyll content. Several growth parameters in honeysuckle cuttings were measured to determine their response to different levels of cadmium in the soil including plant height, dry weight, and leaf area. Relative to the control, 10 and $30 \mathrm{mg} / \mathrm{kg} \mathrm{Cd}^{2+}$ promoted honeysuckle growth as measured by plant height, dry weight, and leaf area, all of which were significantly greater $(P<0.05)$ after 90 days of $\mathrm{Cd}^{2+}$-exposure. In soils containing $80 \mathrm{mg} / \mathrm{kg} \mathrm{Cd}^{2+}$, plant height and leaf area were not significantly different $(P>0.05)$ from the control. In contrast, both plant height and leaf area were significantly lower $(P<0.05)$ in cuttings exposed to 150 and $200 \mathrm{mg} / \mathrm{kg} \mathrm{Cd}^{2+}($ Table 1$)$.

The contents of chlorophyll a, chlorophyll b and total chlorophyll increased significantly $(P<0.05)$ within $10,30 \mathrm{mg} / \mathrm{kg} \mathrm{Cd}^{2+}$ after 90 days of $\mathrm{Cd}^{2+}$-exposure. The chlorophyll a content decreased significantly in leaves of cuttings from plants exposed to $150 \mathrm{mg} / \mathrm{kg} \mathrm{Cd}^{2+}(P<0.05)$, In soils containing $200 \mathrm{mg} / \mathrm{kg} \mathrm{Cd}^{2+}$, the content of chlorophyll a and total chlorophyll decreased significantly $(P<0.05)$ (Table 1).

Table 1

Effects of different concentrations of cadmium on growth parameters and chlorophyll content in Lonicera japonica Thunb. after 90 days. Different letters indicate a significant difference $(P<0.05)$ based on Duncan's multiple range test. Values are the mean $\pm S D(n=3)$.

\begin{tabular}{|c|c|c|c|c|c|c|}
\hline $\begin{array}{l}\text { Cd } \\
\text { concentration }\end{array}$ & Height & Dry weight & Leaf area & $\begin{array}{l}\text { Chlorophyll } \\
\text { a }\end{array}$ & $\begin{array}{l}\text { Chlorophyll } \\
\text { b }\end{array}$ & $\begin{array}{l}\text { Total } \\
\text { chlorophyll }\end{array}$ \\
\hline$(\mathrm{mg} / \mathrm{kg})$ & $(\mathrm{cm})$ & (g) & $\left(\mathrm{cm}^{2}\right)$ & $(\mathrm{mg} / \mathrm{g} \mathrm{FW})$ & $(\mathrm{mg} / \mathrm{g} \mathrm{FW})$ & $(\mathrm{mg} / \mathrm{g} \mathrm{FW})$ \\
\hline 0 & $\begin{array}{l}44.67 \pm 0.58 \\
b\end{array}$ & $\begin{array}{l}6.47 \pm 0.10 \\
d\end{array}$ & $\begin{array}{l}13.20 \pm 0.13 \\
b\end{array}$ & $\begin{array}{l}6.50 \pm 0.05 \\
d\end{array}$ & $\begin{array}{l}2.45 \pm 0.12 \\
d\end{array}$ & $\begin{array}{l}8.95 \pm 0.13 \\
d\end{array}$ \\
\hline 10 & $\begin{array}{l}46.67 \pm 0.58 \\
a\end{array}$ & $\begin{array}{l}8.69 \pm 0.11 \\
b\end{array}$ & $\begin{array}{l}14.18 \pm 0.60 \\
a\end{array}$ & $\begin{array}{l}7.69 \pm 0.12 \\
c\end{array}$ & $\begin{array}{l}3.27 \pm 0.41 \\
a b\end{array}$ & $\begin{array}{l}10.95 \pm 0.29 \\
\text { C }\end{array}$ \\
\hline 30 & $\begin{array}{l}47.33 \pm 1.15 \\
a\end{array}$ & $\begin{array}{l}11.31 \pm 0.50 \\
\text { a }\end{array}$ & $\begin{array}{l}14.63 \pm 0.23 \\
a\end{array}$ & $\begin{array}{l}10.15 \pm 0.02 \\
a\end{array}$ & $\begin{array}{l}3.17 \pm 0.16 \\
a b c\end{array}$ & $\begin{array}{l}13.32 \pm 0.19 \\
a\end{array}$ \\
\hline 80 & $\begin{array}{l}43.83 \pm 0.76 \\
b\end{array}$ & $\begin{array}{l}7.09 \pm 0.18 \\
\mathrm{C}\end{array}$ & $\begin{array}{l}13.13 \pm 0.34 \\
b\end{array}$ & $\begin{array}{l}8.56 \pm 0.17 \\
b\end{array}$ & $\begin{array}{l}2.75 \pm 0.11 \\
\mathrm{~cd}\end{array}$ & $\begin{array}{l}11.32 \pm 0.15 \\
b\end{array}$ \\
\hline 150 & $\begin{array}{l}41.33 \pm 1.53 \\
\text { c }\end{array}$ & $\begin{array}{l}6.54 \pm 0.14 \\
d\end{array}$ & $\begin{array}{l}11.32 \pm 0.14 \\
c\end{array}$ & $\begin{array}{l}5.51 \pm 0.15 \\
\mathrm{e}\end{array}$ & $\begin{array}{l}3.50 \pm 0.34 \\
a\end{array}$ & $\begin{array}{l}9.01 \pm 0.18 \\
d\end{array}$ \\
\hline 200 & $\begin{array}{l}40.83 \pm 0.29 \\
\text { C }\end{array}$ & $\begin{array}{l}5.79 \pm 0.18 \\
\mathrm{e}\end{array}$ & $\begin{array}{l}11.25 \pm 0.23 \\
c\end{array}$ & $\begin{array}{l}5.43 \pm 0.12 \\
\mathrm{e}\end{array}$ & $\begin{array}{l}2.94 \pm 0.07 \\
\text { bc }\end{array}$ & $\begin{array}{l}8.37 \pm 0.18 \\
\mathrm{e}\end{array}$ \\
\hline
\end{tabular}

Effects of $\mathrm{Cd}^{2+}$ levels on ROS levels. The rate of $\mathrm{O}_{2}{ }^{-}$generation in honeysuckle leaves compared to the control was not significantly different $(P>0.05)$ within the $10,30,80 \mathrm{mg} / \mathrm{kg} \mathrm{Cd}^{2+}$ treated samples before the 80 days of $\mathrm{Cd}^{2+}$ exposure. In contrast, the rate of $\mathrm{O}_{2} \cdot{ }^{-}$generation was significantly higher in leaves of cuttings treated with $200 \mathrm{mg} / \mathrm{kg} \mathrm{Cd}^{2+}$ than that in control (Figure 1a). $\mathrm{H}_{2} \mathrm{O}_{2}$ levels were significantly higher $(P<0.05)$ than in the control during the entire duration of the experiment in leaves of cuttings from plants 
exposed to 80,150 , and $200 \mathrm{mg} / \mathrm{kg} \mathrm{Cd}^{2+}$. Notably, $\mathrm{H}_{2} \mathrm{O}_{2}$ levels were markedly increased $(P<0.05)$ at 90 days in leaves of cuttings exposed to all concentrations of $\mathrm{Cd}^{2+}$ (Figure 1b).

Effects of $\mathrm{Cd}^{2+}$ levels on antioxidant enzyme activity. APX activity compared to the control decreased by $10.84 \%$ by day 50 in leaves of cuttings exposed to $10 \mathrm{mg} / \mathrm{kg} \mathrm{Cd}^{2+}$. In sharp contrast, it was significantly higher than that in control after day 80. APX activity steadily increased in leaves of cuttings exposed to 30 , $50,80,150$, or $200 \mathrm{mg} / \mathrm{kg} \mathrm{Cd}^{2+}$ over the entire duration of the experiment (Figure 2a). During the duration of the experiment, DHAR activity in leaves exposed to $10 \mathrm{mg} / \mathrm{kg} \mathrm{Cd}^{2+}$ was significantly lower $(P<0.05)$ than in the control group. In contrast, DHAR activity was significantly increased $(P<0.05)$ compared to the control group leaves in response to the $150 \mathrm{mg} / \mathrm{kg} \mathrm{Cd}^{2+}$ treatment (Figure 2b). MDAR activity consistently maintained an increased level compared to the control in leaves of cuttings exposed to 80, 150 and 200 $\mathrm{mg} / \mathrm{kg}$. Prior to day 70, MDAR activity was raised in leaves of cuttings exposed to 10 and $30 \mathrm{mg} / \mathrm{kg} \mathrm{Cd}^{2+}$ (Figure 2c). GR activity exhibited an increasing trend over the entire duration of the experiment and reached its highest level in leaves of cuttings treated with $200 \mathrm{mg} / \mathrm{kg} \mathrm{Cd}^{2+}$ at day 90 (Figure 2d).

Effects of $\mathrm{Cd}^{2+}$ levels on GSH pool and NPTs content. As illustrated in Figure 3a, the level of GSH significantly increased over time compared with the control in response to all $\mathrm{Cd}^{2+}$ treatments through the 70th day. GSH levels reached a maximum on day 70 in response to the 80,150 , and $200 \mathrm{mg} / \mathrm{kg} \mathrm{Cd}^{2+}$ treatments, increasing by $69.08 \%, 65.39 \%$, and $98.63 \%$, respectively. Glutathione levels gradually decreased after day 80 in leaves of cuttings exposed to 150 and $200 \mathrm{mg} / \mathrm{kg} \mathrm{Cd}^{2+}$. The level of GSSG was significantly higher $(P<0.05)$ than in the control in the 150 and $200 \mathrm{mg} / \mathrm{kg} \mathrm{Cd}^{2+}$ treatments after 80 days (Figure $3 b$ ). The ratio of GSH/GSSG decreased after 80 days in leaves treated with 150 and $200 \mathrm{mg} / \mathrm{kg}$ $\mathrm{Cd}^{2+}$ resulting in no significant $(P>0.05)$ difference with the control at this time interval (Figure 3c). As indicated in Figure 3d, NPTs levels increased in response to the different $\mathrm{Cd}^{2+}$ treatments and were significantly higher than in the control $(P<0.05)$. NPTs content was highest at day 90 in the $80 \mathrm{mg} / \mathrm{kg} \mathrm{Cd}^{2+}$ treatment, but was much lower in the 150 and $200 \mathrm{mg} / \mathrm{kg} \mathrm{Cd}^{2+}$ treatments (Figure 3d).

Effects of $\mathrm{Cd}^{2+}$ levels on proline content. The proline content in leaves of the $10 \mathrm{mg} / \mathrm{kg} \mathrm{Cd}^{2+}$ treatment markedly increased after 70 days suggesting an adaptation to higher $\mathrm{Cd}^{2+}$ saturation levels accumulated over time. Proline content in leaves continually increased over the duration of the experiment in leaves of cuttings from plants exposed to $30,50,80,150$, and $200 \mathrm{mg} / \mathrm{kg} \mathrm{Cd}^{2+}$. On day 90 , proline content was $98.08 \%$ and $157.05 \%$ higher in leaves exposed to 150 , and $200 \mathrm{mg} / \mathrm{kg} \mathrm{Cd}^{2+}$ respectively than in control (Figure 4).

\section{Correlation between $\mathrm{Cd}^{2+}$ levels and measurement indexes. As shown in Figure 5, APX and GR had a} significant positive correlation with $\mathrm{H}_{2} \mathrm{O}_{2}\left(P<0.05, \mathrm{r}_{\mathrm{APX}}=0.9,0.81,0.94,0.96\right.$ and $0.91, \mathrm{r}_{\mathrm{GR}}=0.91,0.64,0.52$, 0.89 and 0.97 , respectively) in the $10,30,80,150$ and $200 \mathrm{mg} / \mathrm{kg} \mathrm{Cd}^{2+}$ treatment. MDAR had a significant positive correlation with $\mathrm{H}_{2} \mathrm{O}_{2}\left(P<0.05, \mathrm{r}_{\mathrm{MDAR}}=0.95,0.84,0.87\right.$, and 0.96 , respectively) in $10,30,80$, and 150 $\mathrm{mg} / \mathrm{kg} \mathrm{Cd}^{2+}$ exposure. GSH had a significant positive correlation with $\mathrm{H}_{2} \mathrm{O}_{2}\left(P<0.05, \mathrm{r}_{\mathrm{GSH}}=0.74\right.$, and 0.54 , 
respectively) in 10 and $30 \mathrm{mg} / \mathrm{kg} \mathrm{Cd}^{2+}$ exposure. NPTs had a significant positive correlation with $\mathrm{H}_{2} \mathrm{O}_{2}$ $\left(P<0.05, \mathrm{r}_{\mathrm{NPTs}}=0.75,0.86\right.$ and 0.89 , respectively) in 10,30 , and $80 \mathrm{mg} / \mathrm{kg} \mathrm{Cd}^{2+}$ exposure. Proline had a significant positive correlation with $\mathrm{H}_{2} \mathrm{O}_{2}\left(P<0.05, \mathrm{r}_{\text {pro }}=0.71,0.76\right.$ and 0.78 , respectively $)$ in $30,80,150$ $\mathrm{mg} / \mathrm{kg} \mathrm{Cd}{ }^{2+}$ exposure. $\mathrm{O}_{2}{ }^{-}$had a significant positive correlation with proline, NPTs, APX, and DHAR $\left(P<0.05, \mathrm{r}=0.60,0.75,0.57\right.$, and 0.59 , respectively) in $80,150 \mathrm{mg} / \mathrm{kg} \mathrm{Cd}^{2+}$ exposure.

RDA and permutation tests of the measurement indexes with $\mathrm{Cd}^{2+}$ levels. As showed in Figure 6, proline, GSH, NPTs, APX, DHAR, MDAR, and GR were positively correlated with $\mathrm{H}_{2} \mathrm{O}_{2}$ and $\mathrm{O}_{2} \cdot{ }^{-}$generation rate in leaves of honeysuckle cuttings exposed to $10 \mathrm{mg} / \mathrm{kg} \mathrm{Cd}^{2+}$ (Figure 6a). Notably, Proline, GSH, and APX were significant predictor variables at the 0.05 probability level $\left(F p r o=25.2, F_{\mathrm{GSH}}=4.56, F_{\mathrm{APX}}=6.54\right)$. Proline, GSH, NPTs, APX, DHAR, MDAR, and GR were positively correlated with $\mathrm{H}_{2} \mathrm{O}_{2}$ and $\mathrm{O}_{2}$. ${ }^{-}$in leaves of honeysuckle cuttings exposed to $30 \mathrm{mg} / \mathrm{kg} \mathrm{Cd}^{2+}$ (Figure $6 \mathrm{~b}$ ). Proline, $\mathrm{GSH}$, and NPTs were significant predictor variables at the 0.05 probability level $\left(F p r o=20.1, F_{\mathrm{GSH}}=4.44, F_{\mathrm{NPTs}}=6.54\right)$. Proline, $\mathrm{GSH}, \mathrm{NPTs}$, APX, DHAR, MDAR, and GR were positively correlated with $\mathrm{H}_{2} \mathrm{O}_{2}$ and $\mathrm{O}_{2}{ }^{-}$in leaves of honeysuckle cuttings exposed to $80 \mathrm{mg} / \mathrm{kg} \mathrm{Cd}^{2+}$ (Figure 6c). Proline, NPTs, APX, and MDAR were significant predictor variables at the 0.05 probability level $\left(F p r o=47.69, F_{\mathrm{NPTs}}=18.20, F_{\mathrm{APX}}=9.15, F_{\mathrm{MDAR}}=6.93\right)$. Proline, NPTs, APX, DHAR, MDAR, and GR were positively correlated with $\mathrm{H}_{2} \mathrm{O}_{2}$ and $\mathrm{O}_{2}{ }^{-}$in leaves of honeysuckle cuttings exposed to $150 \mathrm{mg} / \mathrm{kg} \mathrm{Cd}^{2+}$. In contrast, GSH in the same treatment was negatively correlated with $\mathrm{H}_{2} \mathrm{O}_{2}$ and $\mathrm{O}_{2}{ }^{-}{ }^{-}$(Figure $6 \mathrm{~d}$ ). Proline and APX were significant predictor variables at the 0.05 probability level ( $F$ pro=31.27, $\left.F_{A P X}=12.14\right)$. Proline, APX, DHAR, MDAR, and GR were positively correlated with $\mathrm{H}_{2} \mathrm{O}_{2}$ and $\mathrm{O}_{2}{ }^{-}$in leaves of honeysuckle cuttings exposed to $200 \mathrm{mg} / \mathrm{kg} \mathrm{Cd}^{2+}$. In the same treatment, GSH was negatively correlated with $\mathrm{H}_{2} \mathrm{O}_{2}$ and $\mathrm{O}_{2}{ }^{-}{ }^{-}$(Figure. 6e). Proline and APX were significant predictor variables at the 0.05 probability level $\left(F p r o=51.08, F_{\mathrm{APX}}=9.42\right)$.

\section{Discussion}

$\mathrm{Cd}$ is a non-essential, water soluble element in plant growth. $\mathrm{Cd}^{2+}$ can bind to transporters used by plants to transfer certain essential elements [17]. This reduces the capacity of the plant to absorb, transport, and utilize essential elements and thus affects the growth of plants to varying degrees [10]. Reduction of these elements can be detrimental to the growth of the plant as well as reducing the nutrition provided to humans and livestock when consumed. This is due to shared root transporters between cadmium and $\mathrm{Zn}^{2+}$ through OsZIP 1, and Fe ${ }^{2+}$ through OsIR TI and OsIR T2 which also transport Cd ion to the roots of common agricultural products such as rice causing micronutrient deficiency in supported populations [37]. In the current study, chlorophyll a, b and total chlorophyll content, plant height, dry weight, and leaf area increased in honeysuckle leaves of cuttings exposed to 10 and $30 \mathrm{mg} / \mathrm{kg} \mathrm{Cd}^{2+}$. These finding reveal that honeysuckle is very resistant to cadmium toxicity compared to most plants. Additionally, $\mathrm{Cd}^{2+}$ has been reported to have a stimulating effect on plant growth at low concentrations [38]. In general, mild stress may stimulate plants to initiate a stress response that accelerates growth. The growth of cotton 
callus was stimulated by $550 \mu \mathrm{mol} / \mathrm{L}$ and $700 \mu \mathrm{mol} / \mathrm{L}$ (low concentration) $\mathrm{Cd}^{2+}$ and inhibited by 1000 $\mu \mathrm{mol} / \mathrm{L}$ (high concentration) $\mathrm{Cd}^{2+}[39]$. When plants are exposed to excessive amounts of Cd, reductions in plant growth, mineral nutrients, and biomass appear to be attributable to toxic effects of cadmium [40]. In our study, the growth and chlorophyll content of honeysuckle decreased when the $\mathrm{Cd}^{2+}$ concentration exceeded $80 \mathrm{mg} / \mathrm{kg}$, which was especially evident at $200 \mathrm{mg} / \mathrm{kg}$, where chlorophyll a, b and total chlorophyll contents were severely impacted (Table 1). Decrease in chlorophyll content may also be related to degradation of the chlorophyll structure caused by the accumulation of ROS in response to $\mathrm{Cd}^{2+}$ stress [41].

When plants are exposed to excessive levels of metals, they produce high levels of ROS, a phenomenon that is considered as one of the earliest biochemical changes exhibited by plants in response to metal induced stress [18]. The $\mathrm{H}_{2} \mathrm{O}_{2}$ content in leaves of honeysuckle increased when cuttings were exposed to increasing concentrations of $\mathrm{Cd}^{2+}$ (Figure 1). Low concentrations of $\mathrm{Cd}^{2+}$ have been reported to induce low ROS levels that act as signal molecules in the induction of defense genes against $\mathrm{Cd}^{2+}$ toxicity [42]. However, high concentrations of $\mathrm{Cd}^{2+}$ induce high ROS levels generally causing a serious imbalance to occur in ROS synthesis and degradation. Plants are subjected to oxidative stress when high ROS levels are present posing a physiological challenge. In our study $\mathrm{O}_{2} \cdot{ }^{-}$and $\mathrm{H}_{2} \mathrm{O}_{2}$ levels in honeysuckle leaves increased significantly in response to the 150 and $200 \mathrm{mg} / \mathrm{kg} \mathrm{Cd}^{2+}$ treatments. Similar results were observed in a study of wheat roots showing that $\mathrm{O}_{2} \cdot{ }^{-}$generation rate and $\mathrm{H}_{2} \mathrm{O}_{2}$ content were also increased in response to elevated $\mathrm{Cd}^{2+}$ exposure [43]. Elevated ROS levels can result in the inhibition of enzyme activity, protein oxidation [44, 45], and an inability to manage the higher levels of oxidative damage induced by ROS levels [43].

An important antioxidant system involved in Cd detoxification is the AsA-GSH cycle composed of several antioxidants such as GSH, AsA, and critical antioxidant enzymes APX, MDAR, DHAR, and GR [46]. APX plays a vital role in the antioxidant defense response of plants by catalyzing the conversion of $\mathrm{H}_{2} \mathrm{O}_{2}$ to water at the expense of AsA [24]. In the present study APX activity was increased as the duration of $\mathrm{Cd}^{2+}$ exposure increased and $\mathrm{Cd}^{2+}$ concentration intensified. APX activity had a significant linear correlation with $\mathrm{H}_{2} \mathrm{O}_{2}$ content in all $\mathrm{Cd}^{2+}$-exposed treatment. This suggests that $A P X$ participates in detoxifying $\mathrm{H}_{2} \mathrm{O}_{2}$, and might be a crucial factor in eliminating ROS in elevated $\mathrm{Cd}^{2+}$ stress. In the AsA-GSH cycle, AsA, as an electron donor of $\mathrm{H}_{2} \mathrm{O}_{2}$, produces dehydroascorbic acid (DHA) through the activity of APX and then converts it to AsA through the activity of DHAR when GSH, as a product of GR, is present as an electron donor [47]. In the present study, we also observed that MDAR, DHAR and GR activity levels were elevated as exposure to levels of $\mathrm{Cd}^{2+}$ increased (Figure 2b-d). The enhanced activities of the AsA-GSH cycle may be attributed to the need to maintain a favorable redox status by maintaining sufficient levels of GSH and reduced AsA to overcome the physiological repercussions of oxidation [46].

GSH functions to regulate $\mathrm{H}_{2} \mathrm{O}_{2}$ levels in plant cells and acts as an antioxidant, reducing oxidative stress caused by metal-induced ROS [48]. In our study, GSH content increased and the GSH/GSSG ratio was up- 
regulated in response to the 10 and $30 \mathrm{mg} / \mathrm{kg} \mathrm{Cd}^{2+}$ treatment. A lower level of ROS was also observed at this concentration of cadmium (Figure 1) which could be explained by the key role of GSH in scavenging of ROS. Change in the ratio of GSH/GSSG during the degradation of $\mathrm{H}_{2} \mathrm{O}_{2}$ plays an important role in some redox signaling pathways [49]. GSH content decreased at later testing periods in 150 and $200 \mathrm{mg} / \mathrm{kg} \mathrm{Cd}^{2+}$ treatment, while GSSG content continued to increase. During this period as the GSH/GSSG ratio decreased the ROS levels increased. A decrease in GSH in response to Cd stress suggests that the protective role of GSH against oxidative stress may be significantly reduced as cadmium levels increase beyond a sustainable threshold [50]. NPTs molecules, including GSH, Cysteine, MTs (metallothioneins), and other related substances, contain a high percentage of cysteine sulfhydryl residues that play an important role in the detoxification of metals in plants [51]. In our study, the content of NPTs also increased significantly as the concentration of $\mathrm{Cd}^{2+}$ increased, suggesting that NPTs might have participated in the detoxification of $\mathrm{Cd}^{2+}$ (Figure $3 \mathrm{~d}$ ) which also correlates with the study of $\mathrm{Cd}$ management in perennial ryegrass (Lolium perenne L.) [52]. The concentration of NPTs compounds also increased as the concentration of $\mathrm{Cd}^{2+}$ increased in Brassica pekinensis and B. chinensis, which might have been due to the chelation of sulfhydryl compounds with $\mathrm{Cd}^{2+}[53]$.

In many plants, free proline accumulates in response to a wide range of biotic and abiotic stresses [54]. Proline has multiple functions in stress adaption [55]. Proline acts as an osmoprotectant and an antioxidant by scavenging hydroxyl radicals $\left(\mathrm{OH}\right.$.) and singlet oxygen $\left({ }^{1} \mathrm{O}_{2}\right)$ to alleviate ROS-induced cellular injury [56]. In the current study, proline content increased both as time of exposure to elevated $\mathrm{Cd}^{2+}$ and as the concentration of $\mathrm{Cd}^{2+}$ increased (Figure 4). It is possible that an increase in the concentration of $\mathrm{H}_{2} \mathrm{O}_{2}$ and $\mathrm{O}_{2}{ }^{-}$induced free proline accumulation as the need to eliminate ROS increased in honeysuckle leaves.

Previous studies have demonstrated that cadmium can induce an increase in the level of ROS in cells, whereas enzymatic and non-enzymatic antioxidants play an essential role in reducing excess ROS levels $[20,57-59]$. To expand on this knowledge, we analyzed the relationship between $\mathrm{H}_{2} \mathrm{O}_{2}, \mathrm{O}_{2} \cdot{ }^{-}$., and antioxidants in the leaves of honeysuckle cuttings exposed to various concentrations of $\mathrm{Cd}^{2+}$ by measuring specific antioxidant-related variables and determining their correlations using the RDA and permutation tests. Results indicated that when the content of $\mathrm{H}_{2} \mathrm{O}_{2}$ and $\mathrm{O}_{2}{ }^{-}{ }^{-}$increased in honeysuckle leaves in response to increasing concentrations of $\mathrm{Cd}^{2+}$, proline levels also increased. A positive correlation between proline and $\mathrm{H}_{2} \mathrm{O}_{2}$ and $\mathrm{O}_{2}{ }^{-}{ }^{-}$levels, and significant predictor variables were at the 0.05 probability level in $10,30,80,150$, and $200 \mathrm{mg} / \mathrm{kg} \mathrm{Cd}^{2+}$ exposure (Figure 6). We confirmed that proline in honeysuckle leaves served as the dominant antioxidant in all $\mathrm{Cd}^{2+}$ treatments, and accumulated proline acted as a protective response against oxidative stress [60]. Pearson correlation coefficients and permutation tests analysis (Figure 6) indicated that the level of APX had a significant correlation with $\mathrm{H}_{2} \mathrm{O}_{2}$ content, in addition to proline. APX was an important predictor of oxidative stress in the $10,80,150$ and $200 \mathrm{mg} / \mathrm{kg} \mathrm{Cd}^{2+}$ treatments. These factors suggested that APX, as an antioxidant enzyme, also plays an important role in scavenging $\mathrm{H}_{2} \mathrm{O}_{2}$ in honeysuckle leaves exposed to high concentration of $\mathrm{Cd}^{2+}$. 
GSH was correlated with $\mathrm{H}_{2} \mathrm{O}_{2}$ and $\mathrm{O}_{2}{ }^{-}{ }^{-}$, and significant predictor variables at the $P<0.05$ probability level in honeysuckle leaves of cuttings exposed to 10 and $30 \mathrm{mg} / \mathrm{kg} \mathrm{Cd}^{2+}$. This positive correlation, however decreased as $\mathrm{Cd}^{2+}$ concentration increased, and was even a negative correlation in the 150 and 200 $\mathrm{mg} / \mathrm{kg} \mathrm{Cd}{ }^{2+}$ treatments. This response may occur at high concentrations of $\mathrm{Cd}^{2+}$ when $\mathrm{GSH}$ mechanisms are overwhelmed and unable to act as an effective antioxidant. When GSH is consumed in higher quantities in plant cells, the increasing role of NPTs in scavenging ROS became increasingly evident. NPTs levels were significant predictor variables correlating with the content of $\mathrm{H}_{2} \mathrm{O}_{2}$ and $\mathrm{O}_{2} \cdot{ }^{-}$generation rate in $80 \mathrm{mg} / \mathrm{kg} \mathrm{Cd}^{2+}$ treatments. Compounds containing cysteine sulfhydryl residues including GSH played a major role in alleviating potential oxidative damage.

\section{Materials And Methods}

Plant material. Cuttings selected for this study were healthy, one-year-old honeysuckle (Lonicera japonica Thunb.) from a representative strain cultivated at Liaoning University which continues to be used in additional research in the university's Department of life sciences. The cuttings were obtained in accordance with all relevant institutional, national, and international guidelines and legislation and all appropriate permissions and licenses were obtained for the specimens and materials. The cuttings were cultivated in sterilized sand for ten weeks and then transplanted to a mixture of soil to sand (3:1). The soil was a brown topsoil (0 20 cm, pH 7.06), and was obtained from Liaoning University. The level of basic nutrients in the soil was $0.21 \mathrm{mg} / \mathrm{kg}$ calcium, $97.29 \mathrm{mg} / \mathrm{kg}$ nitrogen, $8.84 \mathrm{mg} / \mathrm{kg}$ phosphorus, 216.98 $\mathrm{mg} / \mathrm{kg}$ potassium, and $1.50 \%$ organic matter. Air-dried soil samples were filtered through a $4.0 \mathrm{~mm}$ sieve for use in the experiment.

Cd exposure. The experiments were conducted in a laboratory in Liaoning University $25 / 17^{\circ} \mathrm{C}$ day/night

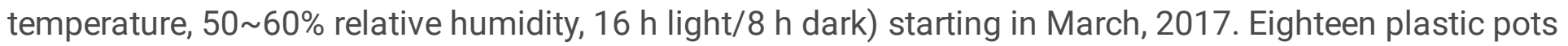
(20 cm diameter $\times 30 \mathrm{~cm}$ height) containing $2.5 \mathrm{~kg}$ of air-dried, disinfected soil were prepared. A $\mathrm{CdCl}_{2} \cdot 2.5 \mathrm{H}_{2} \mathrm{O}$ solution of different concentrations of $\mathrm{Cd}^{2+}$ were randomly added to each pot. Six levels of $\mathrm{Cd}^{2+}$ were administered to the pots, including 0 (control), 10, 30, 80, 150, and $200 \mathrm{Cd}^{2+} \mathrm{mg} / \mathrm{kg}$ soil (3 replicates in each level). The soil was regularly mixed and allowed to come to equilibrium over a period of 40 days. During this time, the soil was mixed and sprayed with water every week to maintain an $80 \%$ water content. Three honeysuckle cuttings with similar growth and height were planted in each pot after the 40 days equilibrium period. Leaves from the cuttings were harvested every ten days from the 50 th through the 90th day after the cuttings were placed in the cadmium-containing soils. Leaf samples were wrapped in tin foil, immediately frozen in liquid nitrogen, and stored at $-80^{\circ} \mathrm{C}$ until subsequent analysis.

Measurement of growth parameters. Height $(\mathrm{cm})$ and leaf area $\left(\mathrm{A}, \mathrm{cm}^{2}\right)$ of plants were measured after 90 days of $\mathrm{Cd}$ exposure. At that time, all plants were collected. Roots were washed with distilled water, submerged in EDTA-Na ${ }_{2}$ for 20 min to balance ion levels, then cleaned with deionized water and immediately dried on filter paper. Lastly, the whole above-ground portion of the plant was placed in a $105^{\circ} \mathrm{C}$ oven to a constant dry weight for the determination of biomass. 
Determination of chlorophyll content. Chlorphyll was extracted from $0.5 \mathrm{~g}$ fresh leaves with $80 \%$ acetone (centrifuging at $5000 \times \mathrm{g}$ ) and the absorbance of the supernatant was measured at 663 and $645 \mathrm{~nm}$ to determine the level of chlorophyll a, chlorophyll b, and total chlorophyll, respectively [61].

Determination of ROS levels. The rate of $\mathrm{O}_{2}{ }^{-}{ }^{-}$generation in leaves was determined by the hydroxylamine hydrochloride method [62] with minor modifications. Initially, $0.1 \mathrm{~g}$ leaves were ground in $3 \mathrm{ml} 0.05 \mathrm{~mol} / \mathrm{L}$ phosphate (K-P) buffer ( $\mathrm{pH} 7.8)$, followed by centrifugation at $5000 \times \mathrm{g}, 3 \mathrm{~min}$ at $4^{\circ} \mathrm{C}$. Subsequently, $0.5 \mathrm{ml}$ supernatant was mixed with phosphate buffer $(\mathrm{pH} 7.8)$ and $1 \mathrm{~mol} / \mathrm{L}$ hydroxylamine hydrochloride and incubated for $20 \mathrm{~min}$ at $25^{\circ} \mathrm{C}$. Then, $17 \mathrm{mmol} / \mathrm{L} \mathrm{p}$-aminobenzene sulfonic acid and $7 \mathrm{mmol} / \mathrm{L} 1-$ naphthylamine were added to the solution and absorbance was measured at $530 \mathrm{~nm}$.

Hydrogen peroxide $\left(\mathrm{H}_{2} \mathrm{O}_{2}\right)$ levels were determined in an extract prepared from $0.5 \mathrm{~g}$ leaves in $2.5 \mathrm{ml}$ propanone, which was then centrifuged at $12000 \times \mathrm{g}$ for $10 \mathrm{~min}$ at $4^{\circ} \mathrm{C}$. The resulting supernatant was added to a mixture of $0.1 \mathrm{ml} 5 \% \mathrm{Ti}\left(\mathrm{SO}_{4}\right)_{2}$ (titanium sulphate) and $0.2 \mathrm{ml} \mathrm{NH}_{3}$ (ammonia), and then centrifuged at $10000 \times \mathrm{g}$ for $10 \mathrm{~min}$ at $4^{\circ} \mathrm{C}$. The resulting precipitate was dissolved in $2 \mathrm{~mol} / \mathrm{L} \mathrm{H}_{2} \mathrm{SO}_{4}$ and then re-centrifuged. The absorbance of the supernatant was measured in a spectrophotometer at $415 \mathrm{~nm}$ [63].

Determination of enzymatic and non-enzymatic antioxidant compounds. A total of $0.5 \mathrm{~g}$ of fresh leaves were ground in $3.5 \mathrm{ml} 50 \mathrm{mmol} / \mathrm{L}$ phosphate buffer (K-P; pH 7.8) containing $1.0 \mathrm{mmol} / \mathrm{L}$ EDTA-Na $2,1.0$ $\mathrm{mmol} / \mathrm{L}$ ascorbate and $2 \%(\mathrm{v} / \mathrm{v})$ polyvinylpyrrolidone (PVP), and $1.5 \mathrm{ml}$ saturated ammonium sulfate. The mixture was then centrifuged at $5000 \times \mathrm{g}$ for $10 \mathrm{~min}$ at $4^{\circ} \mathrm{C}$. The resulting supernatant was used to measure enzyme activity.

Ascorbate peroxidase (APX; EC 1.11.1.11) activity: A $1 \mathrm{ml}$ reaction mixture containing phosphate buffer (pH 7.0), $0.83 \mathrm{ml}$ ascorbate, $0.13 \mathrm{ml} \mathrm{H}_{2} \mathrm{O}_{2}, 0.04 \mathrm{ml}$ crude enzyme was utilized. Ascorbate consumption was measured by the reduction in absorbance at $290 \mathrm{~nm}$ over $1 \mathrm{~min}$. APX activity was calculated using an extinction coefficient of $2.8 \mathrm{~L} /(\mathrm{mmol} \mathrm{cm})[64]$.

Dehydroascorbate reductase (DHAR; EC 1.8.5.1) activity: A $1 \mathrm{ml}$ reaction mixture containing $0.7 \mathrm{ml}$ phosphate buffer, $0.1 \mathrm{ml}$ reduced glutathione (GSH), $0.1 \mathrm{ml}$ dehydroascorbate (DHA), and $0.1 \mathrm{ml}$ crude enzyme extract was utilized. DHAR activity was calculated from the changes of absorbance at $265 \mathrm{~nm}$ over $1 \mathrm{~min}$, using an extinction coefficient of $14 \mathrm{~L} /(\mathrm{mmol} \mathrm{cm})$ [64].

Monodehydroascorbate reductase (MDAR; EC 1.6.5.4) activity: A $1 \mathrm{ml}$ reaction mixture containing phosphate buffer (pH 7.6), $0.9 \mathrm{ml}$ ascorbate, $0.04 \mathrm{ml}$ ascorbate oxidase, $0.03 \mathrm{ml} \mathrm{NADPH}$, and $0.03 \mathrm{ml}$ of crude enzyme extract was utilized. MDAR activity was determined by measuring the consumption of $\mathrm{NADPH}$ as indicated by the change in absorbance at $340 \mathrm{~nm}$ over $1 \mathrm{~min}$, using an extinction coefficient of $6.2 \mathrm{~L} /(\mathrm{mmol} \mathrm{cm})[65]$.

Glutathione reductase (GR; EC 1.6.4.2) activity: A $1 \mathrm{ml}$ reaction mixture containing $0.86 \mathrm{ml}$ oxidized glutathione (GSSG), $0.1 \mathrm{ml} \mathrm{NADPH}$, and $0.04 \mathrm{ml}$ of crude enzyme extract was utilized. GR activity was 
calculated from the change in absorbance at $340 \mathrm{~nm}$ over $1 \mathrm{~min}$, using an extinction coefficient of 2.8 $\mathrm{L} /(\mathrm{mmol} \mathrm{cm})[64]$.

GSH was determined according to the method of Yu et al. [66] with a few modifications. Fresh leaves $(0.15 \mathrm{~g})$ were extracted with $1.75 \mathrm{ml} 5 \%(\mathrm{w} / \mathrm{v})$ sulfosalicylic acid, followed by centrifugation at $12000 \times \mathrm{g}$ for $4 \mathrm{~min}$ at $4^{\circ} \mathrm{C}$. The supernatant was used to determine the reduced and total glutathione content. Initialy, a $0.6 \mathrm{ml} 0.1 \mathrm{~mol} / \mathrm{L}$ phosphate buffer (K-P; pH 7.0; containing $0.5 \mathrm{~mol} / \mathrm{L}$ EDTA) and $50 \mu \mathrm{l} 3 \mathrm{mmol} / \mathrm{L}$ DTNB (5,5'-dithiobis-(2-nitrobenzoic acid)) was added to the supernatant and the content of reduced glutathione was determined by measuring the absorbance of the solution at $412 \mathrm{~nm}$ for $5 \mathrm{~min}$. Then, $0.5 \mathrm{ml}$ phosphate buffer, $50 \mu \mathrm{LTNB}, 0.1 \mathrm{ml} \mathrm{NADPH}(0.4 \mathrm{mmol} / \mathrm{L})$, and $2 \mu \mathrm{l} \mathrm{GR}$ were added to the supernatant and the solution was incubated for $20 \mathrm{~min}$. Total glutathione was determined by measuring absorbance at $412 \mathrm{~nm}$. Oxidized glutathione (GSSG) content was determined based on the difference between the values of total glutathione content and reduced glutathione content (GSSG). The obtained values were used to determine the GSH/GSSG ratio.

Determination of non-protein thiols (NPTs) and proline content. Non-protein thiols (NPTs) were measured as previously described by Sharma et al. [67]. Initially, $0.1 \mathrm{~g}$ of sample was ground in $5 \mathrm{ml} 1 \mathrm{~mol} / \mathrm{L} \mathrm{HCl}$ and $1 \mathrm{~mol} / \mathrm{L}$ EDTA, and centrifuged at $10000 \times \mathrm{g}$ for $3 \mathrm{~min}$ at $4^{\circ} \mathrm{C}$. The supernatant was then added to 0.5 $\mathrm{ml}$ phosphate buffer ( $\mathrm{pH} 7.8$ ), and $0.5 \mathrm{ml} 6 \mathrm{mmol} / \mathrm{L} \mathrm{DTNB}, \mathrm{N}$ levels were determined by measuring the change in absorbance at $412 \mathrm{~nm}$.

Proline content was determined using the acid ninhydrin assay [68]. Initially, $0.1 \mathrm{~g}$ fresh leaves were ground in $5 \mathrm{~mL} 3 \%$ sulfosalicylic acid. The homogenate was centrifuged at $10000 \times \mathrm{g}$ for $3 \mathrm{~min}$ at $4^{\circ} \mathrm{C}$. The supernatant was mixed in a 1:1:1 ratio with glacial acetic acid, and $2.5 \%$ acid ninhydrin, boiled at $100^{\circ} \mathrm{C}$ for $30 \mathrm{~min}$ and finally cooled. Then $6 \mathrm{~mL}$ of toluene was added, after thorough mixing, the chromophorecontaining toluene was separated, absorbance was measured at $520 \mathrm{~nm}$ taking blank toluene as a control.

Statistical analysis. One-way ANOVA followed by a Duncan's multiple range test at a $5 \%$ level was used to statistically analyze the effect of cadmium on plant growth, chlorophyll content, $\mathrm{O}_{2}{ }^{--}$production rate, $\mathrm{H}_{2} \mathrm{O}_{2}$ content, proline content, GSH levels, NPTs content, and antioxidant enzyme activity (APX, DHAR, MDAR and GR). A Pearson correlation coefficient was calculated for each treatment to explore the relationship between $\mathrm{O}_{2}{ }^{--}$production rate, $\mathrm{H}_{2} \mathrm{O}_{2}$ content, proline content, $\mathrm{GSH}, \mathrm{NPT}$ content, APX, DHAR, MDAR, and GR. A redundancy analysis (RDA) and a permutation test were performed for each treatment to determine the key variables explaining changes in the $\mathrm{O}_{2}{ }^{--}$production rate and $\mathrm{H}_{2} \mathrm{O}_{2}$ content. The predictor variables included proline content, GSH, NPTs content, APX, DHAR, MDAR, and GR. A significance level of $P<0.05$ was used in the Pearson correlation analysis, RDA, and Permutation tests. The Pearson correlation analysis, RDA, and permutation tests were carried out in R 3.5.2 [69]. The ANOVA was carried out using SPSS software.

\section{Conclusion}


In the current study, excessive $\mathrm{Cd}^{2+}$ induces an increase of oxidants $\mathrm{H}_{2} \mathrm{O}_{2}, \mathrm{O}_{2}{ }^{-\cdot}$, and the activities of APX, MDAR, DHAR and GR were enhanced with exposure to increasing levels of $\mathrm{Cd}^{2+}$. Additionally, the AsA-GSH cycle was activated in honeysuckle in response to elevated $\mathrm{Cd}^{2+}$. According to the RAD and permutation tests, we confirmed proline and APX serve as the dominant antioxidant and antioxidant enzyme in scavenging ROS in elevated $\mathrm{Cd}^{2+}$. Collectively, GSH and NPTs also act as the secondary antioxidants and their levels increase in response to increasing concentration of $\mathrm{Cd}^{2+}$. In addition, the honeysuckle cutting growth was promoted by the addition of low concentrations ( 10 and $30 \mathrm{mg} / \mathrm{kg}$ ) of $\mathrm{Cd}^{2+}$, but when honeysuckle cuttings were subjected to higher concentrations ( 150 and $200 \mathrm{mg} / \mathrm{kg}$ ) of $\mathrm{Cd}^{2+}$, their capacity to tolerate cadmium was exceeded and plant growth was inhibited.

\section{Declarations}

\section{Acknowledgements}

This research was funded by National Nature Science Foundation of China (31670700, 31370601). Innovative talents support plan for colleges and universities in Liaoning province (LR2018003).

\section{Author information}

These authors contributed equally: Chengcheng Li, Yi Tang.

\section{Contributions}

C.L. and Y.R. participated in the discussion and experimental designs, Y.H. prepared the experiment materials, F.G., Q.W. and W. Y. performed most of the experiments, Y.T. undertook laboratory analyses and drafted the manuscript. All authors read and approved the final manuscript.

\section{Corresponding author}

Correspondence to Yanan Ruan.

\section{Conflicts of Interest}

The authors declare no conflict of interest.

\section{References}

1. Cupit, M., Larsson, O., Meeûs, C. D., Eduljee, G. H. \& Hutton, M. Assessment and management of risks arising from exposure to cadmium in fertilisers-II. Sci. Total Environ, 291, 189-206 (2002).

2. Nahar, K. et al. Polyamine and nitric oxide crosstalk: Antagonistic effects on cadmium toxicity in mung bean plants through upregulating the metal detoxification, antioxidant defense and methylglyoxal detoxification systems. Ecotoxicol. Environ. Saf, 126, 245-255 (2016). 
3. Zou, J. et al. Transcriptional, physiological and cytological analysis validated the roles of some key genes linked Cd stress in Salix matsudana Koidz. Environ. Exp. Bot, 134, 116-129 (2017).

4. Shi, X., Sun, H., Chen, Y., Pan, H. \& Wang, S. Transcriptome sequencing and expression analysis of cadmium (Cd) transport and detoxification related genes in Cd-accumulating Salix integra. Front. Plant Sci, 7, 1577 (2017).

5. Meeûs, C. D., Eduljee, G. H. \& Hutton, M. Assessment and management of risks arising from exposure to cadmium in fertilisers. I. Sci. Total Environ, 291, 167-187 (2002).

6. Jia, L. et al. Hormesis effects induced by cadmium on growth and photosynthetic performance in a hyperaccumulator, Lonicera japonica Thunb. J. Plant Growth Regul, 34, 13-21 (2015).

7. Hasanuzzaman, M. et al. Hydrogen peroxide pretreatment mitigates cadmium-induced oxidative stress in Brassica napus L.: An intrinsic study on antioxidant defense and glyoxalase systems. Front. Plant Sci, 8, 115 (2017).

8. Küpper, H., Parameswaran, A., Leitenmaier, B., Trtílek, M. \& Šetlík, I. Cadmium-induced inhibition of photosynthesis and long-term acclimation to cadmium stress in the hyperaccumulator Thlaspi caerulescens. New Phytol, 175, 655-674 (2007).

9. Lomaglio, T. et al. Effect of short-term cadmium stress on Populus nigra L. detached leaves. J. Plant Physiol, 182, 40-48 (2015).

10. Dalcorso, G., Farinati, S. \& Furini, A. Regulatory networks of cadmium stress in plants. Plant Signal. Behav, 5, 663-667 (2010).

11. Gill, S. S. \& Tuteja, N. Cadmium stress tolerance in crop plants: Probing the role of sulfur. Plant Signal. Behav, 6, 215-222 (2011).

12. Jan, S. et al. Interactive effect of 24-epibrassinolide and silicon alleviates cadmium stress via the modulation of antioxidant defense and glyoxalase systems and macronutrient content in Pisum sativum L. seedlings. BMC Plant Biol, 18, 146 (2018).

13. DalCorso, G., Farinati, S., Maistri, S. \& Furini, A. How plants cope with cadmium: Staking all on metabolism and gene expression. J. Integr. Plant Biol, 50, 1268-1280 (2008).

14. Zhong, M. et al. The phosphoproteomic response of rice seedlings to cadmium stress. Int. J. Mol. Sci, 18, 2055 (2017).

15. Lin, Y. F. \& Aarts, M. The molecular mechanism of zinc and cadmium stress response in plants. Cell. Mol. Life Sci, 69, 3187-3206 (2012).

16. Lou, L. et al. Sulfur protects pakchoi (Brassica chinensis L.) seedlings against cadmium stress by regulating ascorbate-glutathione metabolism. Int. J. Mol. Sci, 18, 1628 (2017).

17. Heyno, E., Klose, C. \& Krieger-Liszkay, A. Origin of cadmium-induced reactive oxygen species production: Mitochondrial electron transfer versus plasma membrane NADPH oxidase. New Phytol, 179, 687-699 (2008).

18. Shahid, M. et al. Heavy-metal-induced reactive oxygen species: Phytotoxicity and physicochemical changes in plants. Rev. Environ. Contam. Toxicol, 232, 1-44 (2014). 
19. Guo, Q. et al. Antioxidative systems, metal ion homeostasis and cadmium distribution in Iris lactea exposed to cadmium stress. Ecotoxicol. Environ. Saf, 139, 50-55 (2017).

20. Mittler, R. Oxidative stress, antioxidants and stress tolerance. Trends Plant Sci, 7, 405-410 (2002).

21. Liu, Y. et al. Cadmium-induced oxidative stress and response of the ascorbate-glutathione cycle in Bechmeria nivea (L.) Gaud. Chemosphere, 69, 99-107 (2007).

22. Foyer, C. H. \& Noctor, G. Ascorbate and glutathione: The heart of the redox hub. Plant Physiol, 155, 218 (2011).

23. Ding, $S$. et al. Exogenous glutathione enhances cadmium accumulation and alleviates its toxicity in Populus $\times$ canescens. Tree Physiol, 37, 1697-1712 (2017).

24. Bashri, G., Prasad, S. M. \& Exogenous IAA differentially affects growth, oxidative stress and antioxidants system in Cd stressed Trigonella foenum-graecum L. seedlings: Toxicity alleviation by up-regulation of ascorbate-glutathione cycle. Ecotoxicol. Environ. Saf, 132, 329-338 (2016).

25. Harada, E., Yamaguchi, Y., Koizumi, N. \& Hiroshi, S. Cadmium stress induces production of thiol compounds and transcripts for enzymes involved in sulfur assimilation pathways in Arabidopsis. $\mathrm{J}$. Plant Physiol, 159, 445-448 (2002).

26. Silvia, K. et al. Production of phytochelatins and glutathione by marine phytoplankton in response to metal stress. J. Phycol, 42, 975-989 (2006).

27. Seth, C. S. et al. Phytoextraction of toxic metals: A central role for glutathione. Plant, Cell Environ, 35, 334-346 (2012).

28. Trovato, M., Mattioli, R. \& Costantino, P. Multiple roles of proline in plant stress tolerance and development. Rend. Lincei, 19, 325-346 (2008).

29. Sivakumar, P., Sharmila, P. \& Saradhi, P. P. Proline suppresses Rubisco activity by dissociating small subunits from holoenzyme. Biochem. Biophys. Res. Commun, 282, 236-241 (2001).

30. Giberti, S., Funck, D. \& Forlani, G. $\Delta 1$-pyrroline-5-carboxylate reductase from Arabidopsis thaliana: Stimulation or inhibition by chloride ions and feedback regulation by proline depend on whether NADPH or NADH acts as co-substrate. New Phytol, 202, 911-919 (2014).

31. Kavi Kishor, P. B. \& Sreenivasulu, N. Is proline accumulation per se correlated with stress tolerance or is proline homeostasis a more critical issue? Plant, Cell Environ, 37, 300-311 (2014).

32. Sharmila, P., Kumari, P. K., Singh, K., Prasad, N. V. S. R. K. \& Pardha-Saradhi, P. Cadmium toxicityinduced proline accumulation is coupled to iron depletion. Protoplasma, 254, 763-770 (2017).

33. Nickelson, J. B., Holzmueller, E. J., Groninger, J. W. \& Lesmeister, D. B. Previous land use and invasive species impacts on long-term afforestation success. Forests, 6, 3123-3135 (2015).

34. Wang, H. H., Koralewski, T. E., McGrew, E. K., Grant, W. E. \& Byram, T. D. Species distribution model for management of an invasive vine in forestlands of eastern Texas. Forests, 6, 4374-4390 (2015).

35. Yan, K., Wu, C., Zhang, L. \& Chen, X. Contrasting photosynthesis and photoinhibition in tetraploid and its autodiploid honeysuckle (Lonicera japonica thunb.) under salt stress. Front. Plant Sci, 6, 227 (2015). 
36. Liu, Z., He, X. \& Chen, W. Effects of cadmium hyperaccumulation on the concentrations of four trace elements in Lonicera japonica Thunb. Ecotoxicology, 20, 698-705 (2011).

37. Atabayeva, S. D. et al. Response of plants to cadmium stress. Int.j.biol.chem, 13, 109-117 (2020).

38. Sobkowiak, R. \& Deckert, J. Cadmium-induced changes in growth and cell cycle gene expression in suspension-culture cells of soybean. Plant Physiol. Biochem, 41, 767-772 (2003).

39. Daud, M. K. et al. In vitro cadmium-induced alterations in growth and oxidative metabolism of upland cotton (Gossypium Hirsutum L.). Sci. World J. 2014, 1-10 (2014).

40. Rizwan, M. et al. Cadmium minimization in wheat: A critical review. Ecotoxicol. Environ. Saf, 130, 4353 (2016).

41. Zhang, X., Li, K. W., Chen, K. J., Liang, J. \& Cui, L. J. Effects of cadmium stress on seedlings growth and active ingredients in Salvia miltiorrhiza. Plant Sci. J, 31, 583-589 (2013).

42. Romero-Puertas, M. C. et al. Cadmium-induced subcellular accumulation of O2.- and $\mathrm{H} 2 \mathrm{O} 2$ in pea leaves. Plant, Cell Environ, 27, 1122-1134 (2004).

43. Srivastava, R. K., Pandey, P., Rajpoot, R., Rani, A. \& Dubey, R. S. Cadmium and lead interactive effects on oxidative stress and antioxidative responses in rice seedlings. Protoplasma, 251, 1047-1065 (2014).

44. Opdenakker, K., Remans, T., Keunen, E., Vangronsveld, J. \& Cuypers, A. Exposure of Arabidopsis thaliana to $\mathrm{Cd}$ or $\mathrm{Cu}$ excess leads to oxidative stress mediated alterations in MAPKinase transcript levels. Environ. Exp. Bot, 83, 56-61 (2012).

45. Iqbal, N. et al. Sulfur in the alleviation of cadmium-induced oxidative stress in plants. Environ. Adapt. Stress Toler. Plants Era Clim. Chang, 20, 429-446 (2012).

46. Wu, Z. et al. Antioxidant enzyme systems and the ascorbate-glutathione cycle as contributing factors to cadmium accumulation and tolerance in two oilseed rape cultivars (Brassica napus L.) under moderate cadmium stress. Chemosphere, 138, 526-536 (2015).

47. Singh, S., Singh, A., Srivastava, P. K. \& Prasad, S. M. Cadmium toxicity and its amelioration by kinetin in tomato seedlings vis-à-vis ascorbate-glutathione cycle. J. Photochem. Photobiol. B Biol, 178, 7684 (2018).

48. Foyer, C. H. \& Noctor, G. Redox homeostasis and antioxidant signaling: A metabolic interface between stress perception and physiological responses. Plant Cell, 17, 1866-1875 (2005).

49. Yadav, S. K. Heavy metals toxicity in plants: An overview on the role of glutathione and phytochelatins in heavy metal stress tolerance of plants. South African J. Bot, 76, 167-179 (2010).

50. Akinyemi, A. J., Faboya, O. L., Olayide, I., Faboya, O. A. \& ljabadeniyi, T. Effect of cadmium stress on non-enzymatic antioxidant and nitric oxide levels in two varieties of maize (Zea mays). Bull. Environ. Contam. Toxicol, 98, 845-849 (2017).

51. Sun, J. et al. Contribution of cell walls, nonprotein thiols, and organic acids to cadmium resistance in two cabbage varieties. Arch. Environ. Contam. Toxicol, 64, 243-252 (2013).

52. Jia, H. et al. Exogenous phosphorus treatment facilitates chelation-mediated cadmium detoxification in perennial ryegrass (Lolium perenne L.). J Hazar Mater, 389, 121849 (2020). 
53. Liu, C. P., Shen, Z. G. \& Li, X. D. Accumulation and detoxification of cadmium in Brassica pekinensis and B. chinensis. Biol. Plant, 51, 116-120 (2007).

54. Ben Rejeb, K., Abdelly, C. \& Savouré, A. How reactive oxygen species and proline face stress together. Plant Physiol. Biochem, 80, 278-284 (2014).

55. Szabados, L. \& Savouré, A. Proline: a multifunctional amino acid. Trends Plant Sci, 15, 89-97 (2010).

56. Yilmaz, D. D. \& Parlak, K. U. Changes in proline accumulation and antioxidative enzyme activities in Groenlandia densa under cadmium stress. Ecol. Indic, 11, 417-423 (2011).

57. Moreira, I. N., Mourato, M. P., Reis, R. \& Martins, L. L. Oxidative stress induced by cadmium and copper in Brassica rapa leaves: Indicators of Stress, oxidative damage, and antioxidant mechanisms. Commun. Soil Sci. Plant Anal, 46, 2475-2489 (2015).

58. Gratão, P. L. et al. Cadmium stress antioxidant responses and root-to-shoot communication in grafted tomato plants. BioMetals, 28, 816 (2015).

59. Hojati, M. et al. Cadmium and copper induced changes in growth, oxidative metabolism and terpenoids of Tanacetum parthenium. Environ. Sci. Pollut. Res, 24, 1-12 (2017).

60. Natarajan, S. K. et al. Proline dehydrogenase is essential for proline protection against hydrogen peroxide-induced cell death. Free Radic. Biol. Med, 53, 1181-1191 (2012).

61. Arnon, D. I. Copper enzymes in isolated chloroplasts polyphenoloxidase in Beta vulgaris. Plant Physiol, 24, 1-15 (1949).

62. Yang, H., Wu, F. \& Cheng, J. Reduced chilling injury in cucumber by nitric oxide and the antioxidant response. Food Chem, 127, 1237-1242 (2011).

63. Patterson, B. D., MacRae, E. A. \& Ferguson, I. B. Estimation of hydrogen peroxide in plant extracts using titanium (IV). Anal. Biochem, 139, 487-492 (1984).

64. Nakano, Y. \& Asada, K. Hydrogen peroxide is scavenged by ascorbate-specific peroxidase in Spinach chloroplasts. Plant Cell Physiol, 22, 867-880 (1981).

65. Duarte, B., Caetano, M., Almeida, P. R., Vale, C. \& Caçador, I. Accumulation and biological cycling of heavy metal in four salt marsh species, from Tagus estuary (Portugal). Environ. Pollut, 158, 16611668 (2010).

66. Yu, C. W., Murphy, T. M. \& Lin, C. H. Hydrogen peroxide-induced chilling tolerance in mung beans mediated through ABA-independent glutathione accumulation. Funct. Plant Biol, 30, 955-963 (2003).

67. Sharma, S. S. et al. Cadmium toxicity to barley (Hordeum vulgare) as affected by varying Fe nutritional status. Plant Sci, 166, 1287-1295 (2004).

68. Bates, L. S., Waldren, R. P. \& Teare, I. D. Rapid determination of free proline for water-stress studies. Plant Soil, 39, 205-207 (1973).

69. R Development Core Team, R. R: A Language and Environment for Statistical Computing. Vienna, Austria, ISBN 3900051070 (2015).

\section{Figures}



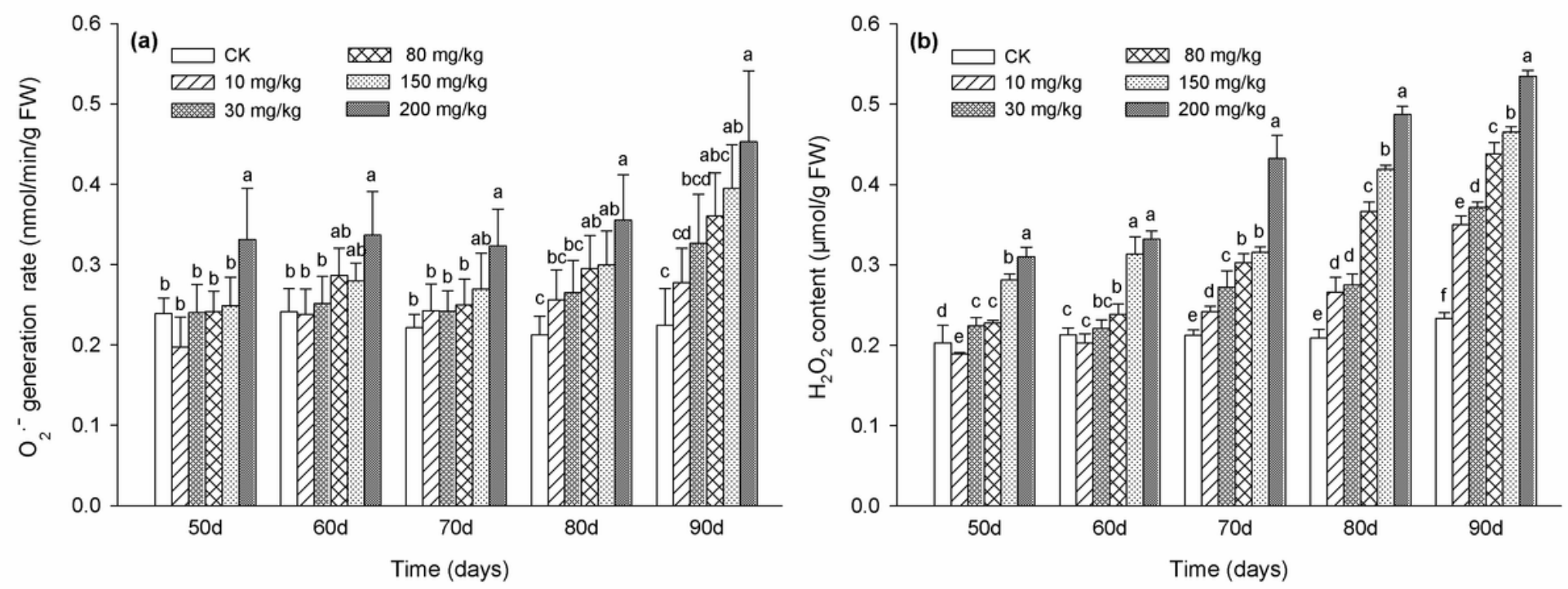

Figure 1

Rate of superoxide radical (02.-) generation (a) and hydrogen peroxide (H2O2) levels (b) in leaves of Lonicera japonica Thunb. cuttings exposed to different concentrations of $\mathrm{Cd} 2+$. Different letters indicate a significant difference $(P<0.05)$ based on Duncan's multiple range test. Values are the mean $\pm S D(n=3)$. 

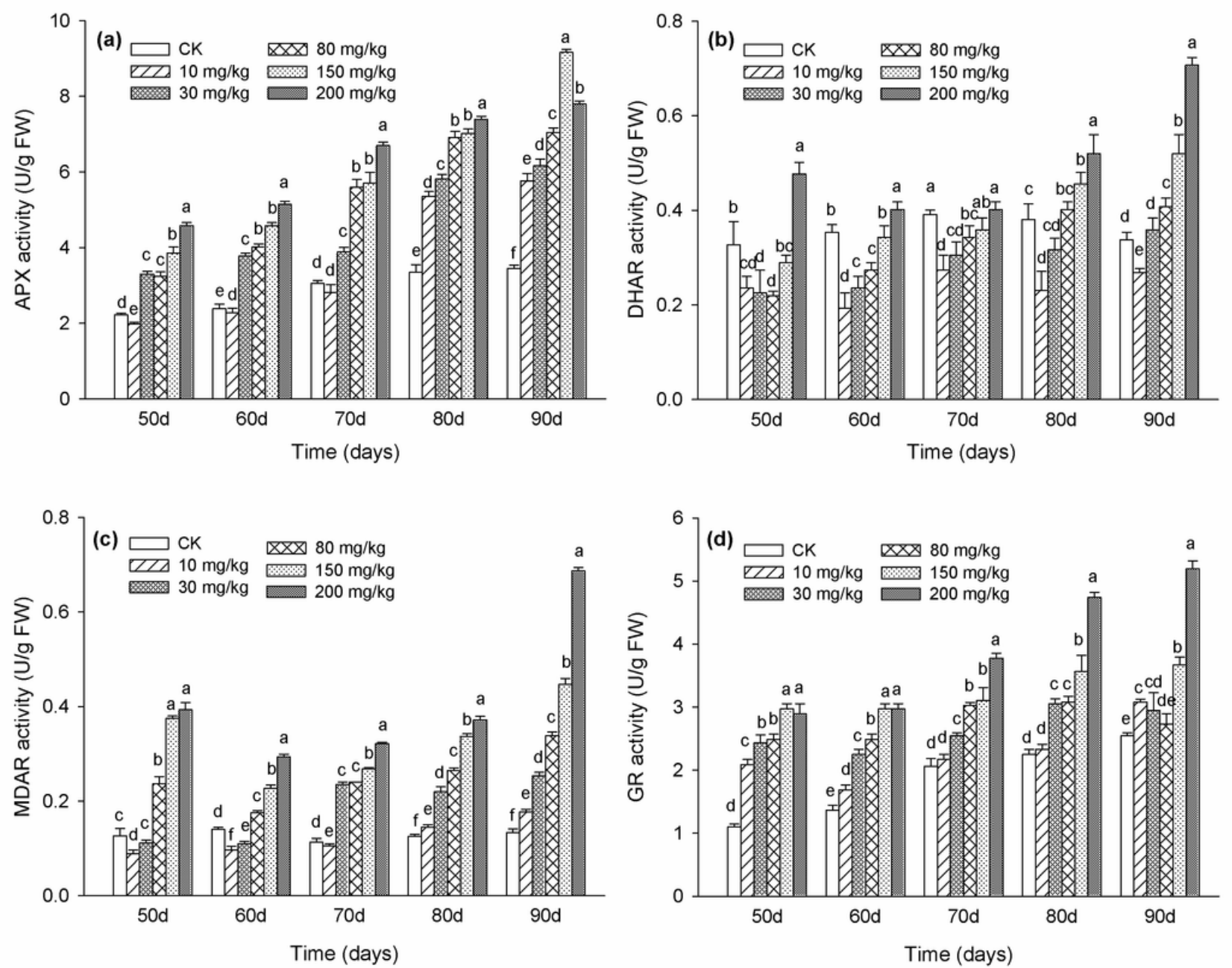

Figure 2

APX (ascorbate peroxidase) (a), DHAR (dehydroascorbate reductase) (b), MDAR (monodehydroascorbate reductase) (c) and GR (glutathione reductase) (d) activities in leaves of Lonicera japonica Thunb. cuttings exposed to different concentrations of $\mathrm{Cd} 2+$. Different letters indicate a significant difference $(P<0.05)$ based on Duncan's multiple range test. Values are the mean $\pm S D(n=3)$. 

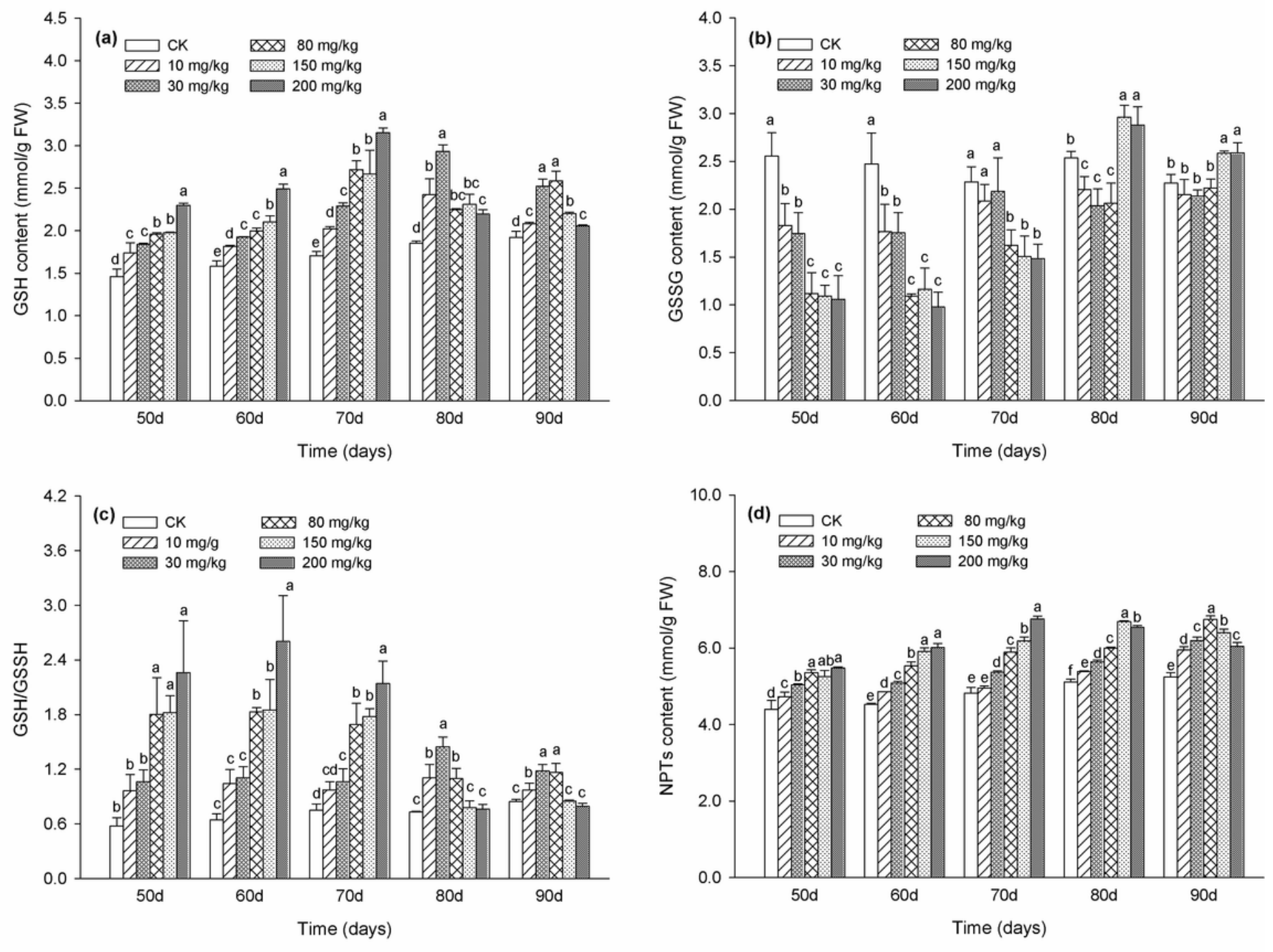

\section{Figure 3}

GSH (reduced glutathione) (a), GSSG (oxidized glutathione) (b), GSH/GSSG (c) and NPTs (non-protein thiols) (d) in leaves of Lonicera japonica Thunb. cuttings exposed to different concentrations of cadmium. Different letters indicate a significant difference $(P<0.05)$ based on Duncan's multiple range test. Values are the mean $\pm S D(n=3)$. 


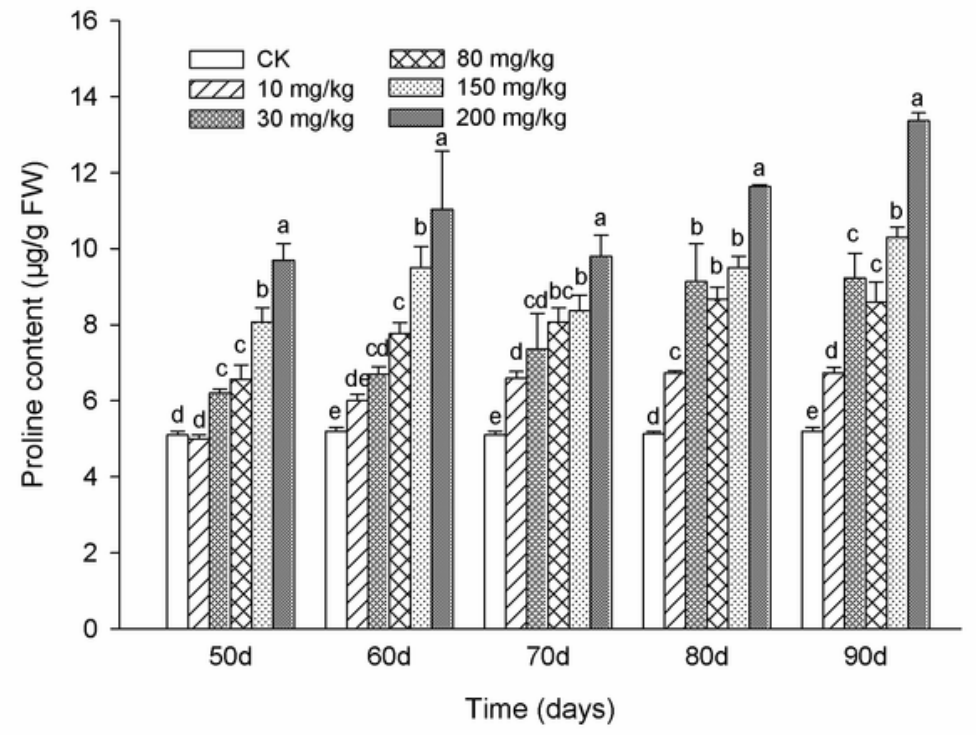

Figure 4

Proline levels in leaves of Lonicera japonica Thunb. cuttings exposed to different concentrations of Cd2+. Different letters indicate a significant difference $(P<0.05)$ based on Duncan's multiple range test. Values are the mean $\pm S D(n=3)$. 

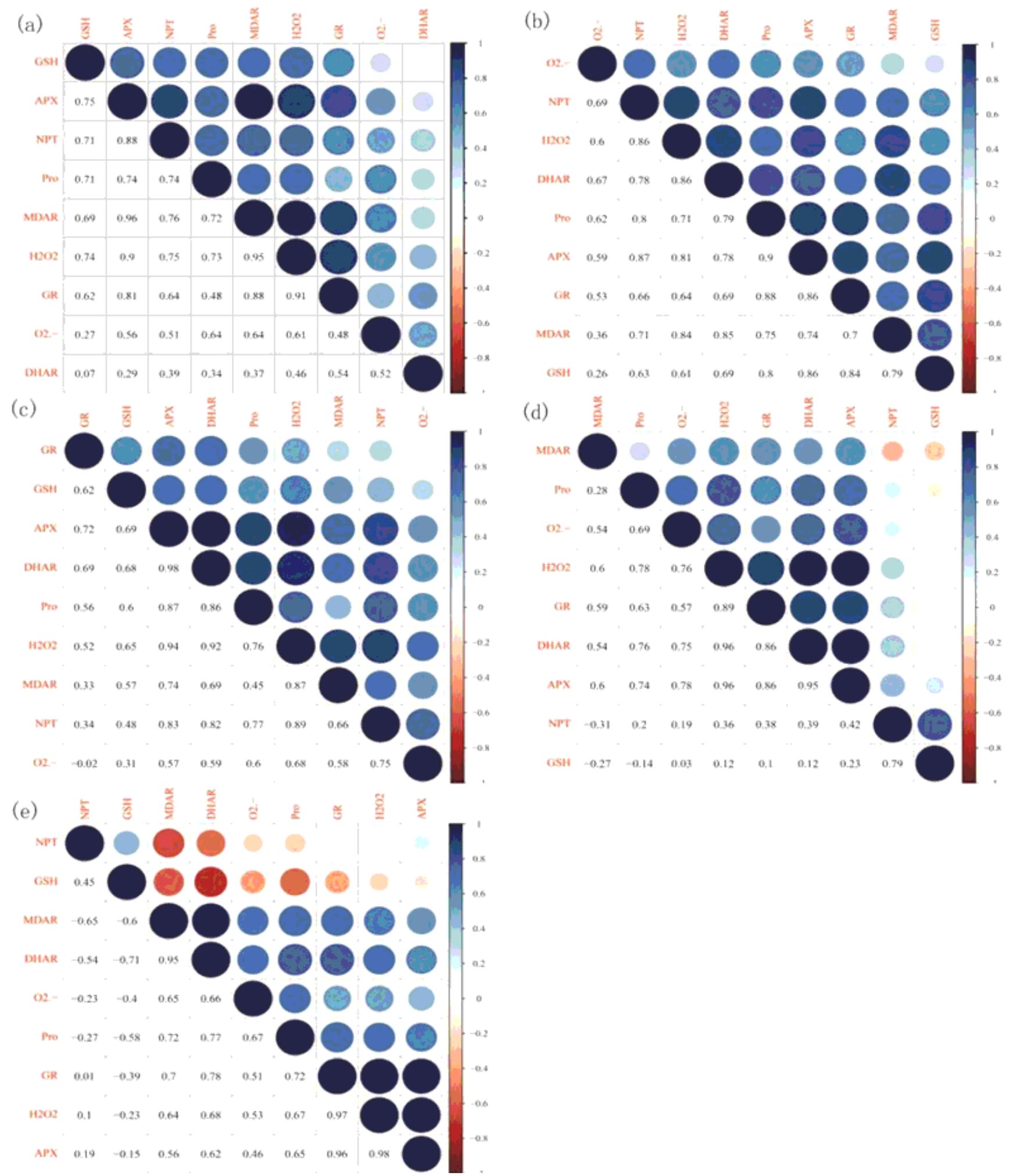

\section{Figure 5}

The Pearson correlation coefficients among the measured variables in leaves of Lonicera japonica Thunb. cuttings exposed to different Cd2+ treatments. (a) $10 \mathrm{mg} / \mathrm{kg} \mathrm{Cd2+;} \mathrm{(b)} 30 \mathrm{mg} / \mathrm{kg} \mathrm{Cd} 2+$; (c) $80 \mathrm{mg} / \mathrm{kg}$ $\mathrm{Cd} 2+$; (d) $150 \mathrm{mg} / \mathrm{kg} \mathrm{Cd} 2+;$ (e) $200 \mathrm{mg} / \mathrm{kg} \mathrm{Cd} 2+$. 

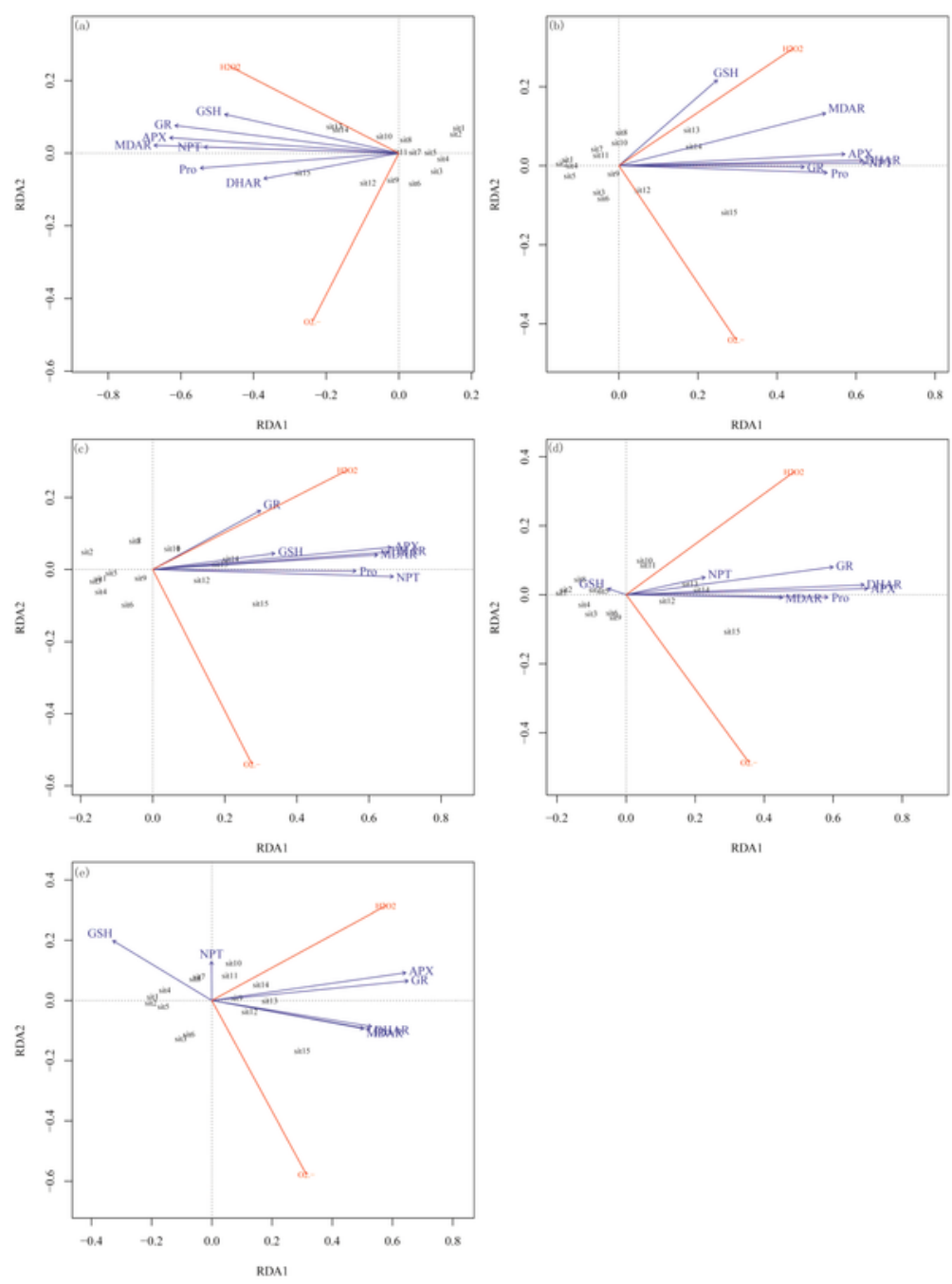

Figure 6

Triplot of the redundancy analysis (RDA) of $\mathrm{H} 2 \mathrm{O} 2$ and 02.- generation rate in leaves of Lonicera japonica Thunb. cuttings exposed to different Cd2+ treatments. (a) $10 \mathrm{mg} / \mathrm{kg} \mathrm{Cd} 2+$; (b) $30 \mathrm{mg} / \mathrm{kg} \mathrm{Cd} 2+$; (c) 80 $\mathrm{mg} / \mathrm{kg} \mathrm{Cd} 2+;$ (d) $150 \mathrm{mg} / \mathrm{kg} \mathrm{Cd} 2+$; (e) $200 \mathrm{mg} / \mathrm{kg} \mathrm{Cd} 2+$. 